\title{
Retailers’ Internationalization in Emerging Markets: A Comparative Study of a French and a Local Retailer's Key Success Factors in Brazil
}

\author{
Mbaye Fall Diallo ${ }^{1,2}$ \\ ${ }^{1}$ The Univ Lille Nord de France, Skema Business School, France \\ ${ }^{2}$ Lille School of Management Research Center (LSMRC), France \\ Correspondence: Mbaye Fall Diallo, IMMD, 6 rue de l'Hôtel de ville, BP59 59051, Roubaix Cedex, France. Tel: \\ 33-6-3069-8587. E-mail: mbayediallo2003@yahoo.fr
}

Received: May 2, 2012

Accepted: May 15, 2012

Online Published: September 3, 2012

doi:10.5539/ibr.v5n10p91

URL: http://dx.doi.org/10.5539/ibr.v5n10p91

\begin{abstract}
The internationalization of retail operations in emerging markets is today one of the most important decisions of mass retailers. This phenomenon has been highlighted by past research, at the micro level as well as the macro-environment. In this paper, we will focus on the key success factors of a retail company in an emerging economy (Brazil). In this respect, we used a case study to compare the key success factors of a foreign and a local retailer considering two increasingly interesting theories in strategic marketing: the core competences theory and the organizational culture theory. The results showed that the international retailing success on the Brazilian market can be well explained by these two theories. Factors for this international retailing success that have been underlined are store format and localization, customer relationship, competitive strengths and organizational culture. However, the local retailer's challenge is now to do as well as the foreign retailer, or better, taking into account the two theories mentioned above. Theoretical and managerial implications of these findings will be provided.
\end{abstract}

Keywords: retail internationalization, core competence theory, organizational culture, Brazil

\section{Introduction}

According to Pederzoli (2006), over the past few years, the trend in the retailing sector has been a global standardization of consumption behaviors and lifestyles. Considering this development, retailers are focusing on a global-scale effort. Actually, as far as a retail strategy is concerned, it is wise, maybe essential, to think "international".

Dawson (1994, p.267), defined international retail operations as "Operations, by a single firm or an alliance, of shops or other forms of retail distribution in more than one country". Early studies and empirical ones have listed several factors motivating retail firms to internationalize their activities, and have illustrated the complexity and the influences prevailing in the international retail decision-making process. To be more specific, Treadgold (1988) identified various "push" and "pull" factors associated with both the macro and micro environments. Among the push factors prevail industry competition, economy, legislation, and domestic saturation, while the pull factors include, for instance, economic and political stability of global markets and profit opportunities in the oversea market (Hutchinson et al., 2007). In the 1990s, pull factors, i.e. international opportunities for growth, were considered as more important for the retail internationalization. As a consequence, a study on the reasons for such a retail internationalization should focus on both internal factors specific to the organization, and external environmental motives (Alexander \& Myers, 2000; Vida \& Fairhust, 1998).

Other authors also noted that, most of the time, retailers tend to internationalize their activities in order to exploit a competitive or a differential advantage (Vida \& Fairhust, 1998; Dupuis \& Fournioux, 2005). As Burt \& Mavrommatis (2006, p.398) noted: "an original concept or a unique and distinctive retail product is the source of competitive advantage for global retailers”. In this respect, we can distinguish two main kinds of retailers in the international markets: mass retailers (e.g. Wal-Mart, Carrefour, Tesco, etc.) and smaller specialty retailers dealing with international operations (e.g. H\&M, Zara, Decathlon, etc.). Mass retailers' target segments may be 
premium segment, mass market segment or mass market and premium segment (Meyer \& Yen, 2006). As for the others, "differentiation is marked by a niche strategy and brand recognition, which focuses on a narrow group of products, a clearly defined market sector, or a specific customer segment" (Hutchinson, Alexander, Quinn, \& Dohery, 2007, p. 98).

The main objective of this research is to compare a French retailer's key success factors (Carrefour) with those of a local chain (Extra) on the Brazilian market mainly based on 'core competence' and organizational culture frameworks. In fact, previous research has investigated firms' internationalization in emerging markets. However, the impacts caused by both 'core competence' and organizational culture have not been studied together regarding retailers' key success factors in these markets. According to Fleury (2009, p. 2), "culture and competence are fairly well-known topics; both are part of the academic agenda and are widely discussed in day-to-day debates within organizations". Yet, the combination of these two frameworks can bring interesting insights into the retail internationalization in emerging markets. This research is also a reaction to scholars' call for more research in emerging markets (see Diallo, 2012). For these researchers, emerging markets "present significant socioeconomic, demographic, cultural, and regulative departures from the assumptions of theories developed in the Western world and challenge our conventional understanding of constructs and their relations" (Burgess \& Steenkamp, 2006, p.337).

This study will be divided as follows: first, we will make a synthetical literature review regarding the 'core competence' theory and the organizational culture theory in relation with international retail strategies. Then, we will use a case study focused on the Brazilian retail market. In the third part, we will present and discuss the results. To finish, we will emphasize the theoretical and managerial benefits of this study, point out its limits and suggest future research orientations.

\section{Literature Review}

Two general theories developed in the international business area are particularly relevant in this research. On the one hand, the 'core competence' theory can be a starting point to understand the retailers' internationalization and their success in emerging markets. On the other hand, based on the strategic field, organizational culture can be seen as a key factor explaining retailers' success in emerging markets.

\subsection{Core Competences}

Increasing attention has recently been given to the concept of 'core competence' by managers, decision makers and scholars. The 'core competence' theory is part of the strategy theory introduced by Prahalad \& Hamel (1990) in the business literature. The basic premise of this concept is that the strategy has to be directed inside the corporation toward resources, capabilities and competences. The concept of core competence may be considered as a complex one as some authors used a wider term in the literature to explain this same reality (i.e., resource-based theory) while other authors preferred another concept close but different (i.e., capabilities). The idea behind the concept of core competence is that a "firm's ability to gain and keep profitable markets segments depends on its ability to gain and defend advantageous positions in underlying resources important to production and distribution" (Conner, 1991, p. 121-122). Prahalad \& Hamel (1990) defined core competences as "the collective learning in the organization, especially how to coordinate diverse production skills and integrate multiple streams of technologies".

As for the resource-based theory, it is a tool that allows us to know what resources are available to a company. This theory is criticized in a sense that the basis for a competitive advantage of a firm lies mainly in the application of the set of valuable resources available for this firm. Resources can be defined as "all assets, capabilities, organizational processes, firm attributes, information, knowledge, etc, controlled by a firm that enable the firm to conceive and implement strategies that improve its efficiency and effectiveness" (Daft, 1983; Barney, 1991, p.101). In this sense, there are many ways of creating a competitive advantage. For instance, Barney (1991) supported that a firm resource must have four main attributes: it must be valuable, rare among the firm's current and potential competition, imperfectly imitable, and there cannot be any strategically equivalent substitutes.

Capabilities must also be differentiated from the concept of 'core competence'. "The capabilities of a firm are what it can do as a result of teams of resources working together and most of the time, higher capabilities of a firm is likely those which derive from an integration of individual functional capabilities”(Grant, 1991). For instance, in the retailing sector, Wal-Mart has a high quality team management, a strong ability to practice aggressive price competition and to avoid labor unions. 
However, for Prahalad \& Hamel (1990), the central concept of corporate strategy is 'core competence'. They believe that a core competence has many characteristics: it is easier to enter many markets; it increases the profits generated by customers; and it is difficult for competitors to imitate. Besides, use is not a factor that diminishes 'core competence'. In fact, "unlike physical assets, which do deteriorate over time, competencies are enhanced as they are applied and shared" (Prahalad \& Hamel, 1990). However, we must stress that competences still need to be nurtured and protected from competitors.

The concept of 'core competence' has recently been applied to the retail sector (Cao \& Dupuis, 2009). The authors distinguished between 'resources' and 'competences' as it was done in past research, defining the core competence of a retailer as "a way of deploying the firm's resources that allow it to perform better, in a similar environment, than its direct or potential competitors, and to create value perceived as such by consumers and the other players involved in the retail chain” (p.351).

\subsection{Organizational Culture}

Organizational culture refers to the general culture within a company or organization, and it is also often referred to as corporate culture even though the two concepts are different as corporate culture encompasses a blend of the values, beliefs, taboos, symbols, rituals and myths all companies develop over time. There are many organizational culture classifications. For instance, Hofstede (1981) identified five dimensions of culture in his study of national influences: power distance, uncertainty avoidance, individualism/collectivism, masculinity/ femininity and long/short term orientation. Power distance expresses the degree to which a society expects differences in terms of power. Uncertainty avoidance reflects the extent to which a society accepts uncertainty and risk. Individualism and collectivism are opposed and refer to the extent to which people are expected to stand up for themselves, or alternatively act predominantly as a member of the group or organization. Masculinity vs. femininity refers to the value placed on traditional male or female values. Male values, for instance, include competitiveness, assertiveness, ambition and the accumulation of wealth and material possessions. Long vs. short term orientation describes a society's "time horizon" or the importance attached to the future versus the past and present.

Furthermore, according to Deshpande, Farley, \& Webster (1993), organizations can have four cultures: first, the hierarchical culture emphasizes established procedures, rules and uniformity. Second, the clan culture stresses loyalty, tradition and commitment to the firm. Third, the market culture focuses on competitive actions and achievement. Finally, an organization with an adhocracy culture is entrepreneurial, creative and flexible. According to these authors, an organization can be classified in one of those four cultures.

Morgan (1997) puts forward four essential strengths of the organizational culture approach. First, it stressed the human side of organizational life, and found significance and learning in its most mundane aspects. Second, it explains the importance of creating appropriate systems of shared meaning to help people work together for a common goal. Third, it makes the members acknowledge the impact of their behavior on the organization's culture. Finally, it reinforces the idea that the perceived relationship between an organization and its environment is also affected by the organization's basic assumptions.

\section{Methodology: Case Study}

This paper includes a case study research to explore the key success factors of a retailer's internationalization in an emerging market. The reasons for such a methodology are, first of all, that it gives us rich insights of these processes (Yin, 1994). Then, the exploratory nature of this research suggests that a case study may be a relevant methodology. Finally, this research is applied to a specific context (i.e. Brazil).

\subsection{Study Units}

\subsubsection{Retailers Investigated}

Two mass retailers are involved in this research: Carrefour and Extra (Group Pao Açucar). Carrefour is the largest grocery retailer in Europe. It operated about 14,990 stores in 30 countries, with sales of US\$102.442 billion during the 2007 fiscal year and has 490,042 employees (Carrefour annual report, 2007). Retailer Extra is the second largest retailer in Latin America after Wal-Mart, and has operations in Brazil, Argentina, Colombia. It was the first foreign retailer to find its place in Brazilian stores in 1975. It is now the largest retailer in the country. Brazil is the third largest contributor of Carrefour in terms of operating income. In order to have a more precise idea of the retail success of Carrefour on the Brazilian market, we compare its strategy to that of its competitor Pao Açucar, a local retailer. The Group Pao Açucar is now the second biggest retailer on the Brazilian market in terms of retail market shares. 


\subsubsection{The Market Study}

This research is based on a survey undertaken on the Brazilian market. Brazil is an emerging market and a BRIC nation which remains one of the first market concerned by retail expansion (Alexander \& de Lira e Silva 2002; AT Kearney 2010; Diallo, 2012). The Brazilian retail market is today attractive for global retailers "considering the country's large population and the relatively stable macroeconomic conditions that had emerged in recent years" (De Angelo, Eunni \& Fouto, 2010, p.204). Brazil is an emerging market and a part of what is called BRICs (Brazil, Russia, India and China). It is the largest national economy in Latin America, the world's tenth largest economy at market exchange rates and the ninth largest in purchasing power parity (PPP), with $\$ 1,313.590$ billion of GNP, according to the International Monetary Fund (2008). Brazil, and indeed South America as a whole, is becoming more important on the global retail stage. With the consumer market growing, an increasing number of foreign retailers are expanding there (Diallo, 2009; Planet Retail, 2007).

Brazil's top retailers are leading multinational retailers who are investing huge sums in this increasingly competitive market. In fact, Brazil's foodservice industry is facing significant changes as global companies continue to invest in the market which has benefited from economic recovery, political stability and growth in tourism. A report published by Planet Retail, The Brazilian Foodservice Market, shows that foodservice sales in Brazil will keep on increasing, reaching BRL103 billion (USD47.2 billion) in 2012 (Planet retail, 2007).

\subsection{Data Collection}

We used two kinds of data: primary and secondary data. The primary data are composed of in-depth interviews with managers of the international retailer Carrefour and its local competitor retailer Extra (hypermarket chain of the Group Pao Açucar). As for the secondary data, it includes the annual reports of the retailers involved and the specialized economic press. Secondary data analysis's aim is to know more about the retailers involved in the study whereas the purpose of the interviews with managers is to identify the key success factors of Carrefour and those of Extra on the Brazilian market.

The interviews were conducted using an in-depth interview guide. We also used a technique usually adopted by researchers: the method of direct quotations. Four in-depth interviews were conducted in Brasilia with store managers and department's managers of Carrefour. Four other in-depth interviews were conducted in the same city with managers and department's managers of Extra (hypermarket chain of the Pao Açucar group). These two retailers were chosen for their representativeness at a national level and for their success in the Brazilian retail industry. Each interview lasted about an hour and was fully recorded and transcribed.

\subsection{Data Analysis}

Data was analyzed using content analysis. One of the main advantages of content analysis is the condensation of data to get a simplified representation. Krippendorff (2004, p.18) defined content analysis as "a technique for making replicable and valid inferences from texts (or other meaningful matter) to the contexts of their use".

For researchers who consider using content analysis, several advantages can be associated to it. In this research, content analysis is used for three main reasons. First, content analysis allows both quantitative and qualitative operations. Second, content analysis can provide valuable historical/cultural insights over time through texts analysis. Third, it permits to stay close to the text which can alternate between specific categories and relationships.

The Sphinx Lexica software was chosen as an assisting tool for our data analysis. In the open coding phase, we first identified the activities where Carrefour was successful and then tried to see whether there was a link between these successful activities and our theoretical frameworks, i.e. 'core competence' theory and organizational culture theory. The same process was performed for the local retailer Extra. The results are analyzed in the next section.

\section{Results and Comments}

\subsection{The Key Success Factors of Carrefour in Brazil}

The success of Carrefour in the Brazilian market is based on several factors. Among these factors, four features related to 'core competence' theory and organizational culture can be mentioned.

- Store Formats and Localization

Carrefour has historically seen most of its internationalization strategy rooted in a single format, the hypermarket (Burt, Davies, Dawson, \& Sparks, 2008). However, after a merger with another retailer in 1999, Carrefour clearly shifted into a multi-format internationalization strategy. The merger also brought the limited line discount format into this group. Carrefour also is the first mover in the Brazilian market. This is why it was able to settle 
in the heart of Brasilia. Table 1 shows some quotations from the interviews explaining how it was relevant for the success of Carrefour on the Brazilian market.

\section{- Consumer Relationship}

Relationship with consumers is a key element in the success of any mass retailer. Customer relationship management is a broadly recognized, widely-implemented strategy for managing and nurturing a company's interactions with clients and sales prospects. Carrefour has always been aware of the importance of customer relationship and is using it in order to find, attract, and win new clients, nurture and retain those the company already has, entice former clients back into the fold, and reduce the costs of marketing and client service. It has for instance launched own store brands, credit cards earlier than its competitors in the Brazilian market (see table 1).

\section{- Competitive Strengths}

Being competitive is a critical issue for retailers evolving in the retail environment as more and more retailers are in competition in the retail market. Competition may give incentives for self-improvement. For example, if two retailers are competing, they will hopefully improve their products and service to increase sales. Carrefour's success is mainly due to several key competitive points. For example, launching its store brands has been a key strategy to attract consumers in the segments $\mathrm{C}$ and $\mathrm{D}$ in the Brazilian market. The strategy aimed to support and to strengthen an aggressive pricing strategy. The focus on its image has also been a key element in the competitive tools of Carrefour (see table 1).

\section{- Organizational Culture}

The concept of organizational culture has now gained wide acceptance in the marketing literature. It is a way to understand human systems. For Carrefour, each aspect of its organizational culture can be seen as an important environmental condition affecting its system and subsystems. Carrefour has for instance a high level of standardization as the latter is a part of its history in retail markets. This allows it to be consistent with its will to cut cost and to charge prices that suit all consumers without sacrificing quality. Carrefour puts also an emphasis on respect for the law on workers' remuneration, paid holidays, etc. Table 1 gives quotations from the interviews about this dimension on the success of Carrefour in Brazil.

Table 1. Verbatim and dimensions of 'core competence’ theory and organizational theory for Carrefour

\begin{tabular}{|c|c|c|c|}
\hline $\begin{array}{l}\text { Store format and } \\
\text { localization }\end{array}$ & Consumer relationship & Competitive strengths & Organizational culture \\
\hline $\begin{array}{l}\text { "Hypermarket as the main } \\
\text { format" } \\
\text { "Diversifying retail formats } \\
\text { in order to target all kinds of } \\
\text { consumers" }\end{array}$ & $\begin{array}{l}\text { "Customer orientation since } \\
\text { many years now" } \\
\text { "Offering our store brands } \\
\text { using the name of the store } \\
\text { in order to satisfy all } \\
\text { consumers segments" }\end{array}$ & $\begin{array}{l}\text { "Our store brands are } \\
\text { present in several product } \\
\text { categories" } \\
\text { "Relying on our brand } \\
\text { awareness" }\end{array}$ & $\begin{array}{l}\text { "A certain adaptation to the local } \\
\text { culture but standardization } \\
\text { remains strong" } \\
\text { "Moving to a customer-oriented } \\
\text { organizational cultural since } \\
\text { many years" }\end{array}$ \\
\hline $\begin{array}{l}\text { "Trying to open more stores } \\
\text { in the discount format" }\end{array}$ & $\begin{array}{l}\text { "Offering store credit cards } \\
\text { to consumers to improve } \\
\text { store loyalty" } \\
\text { "Giving many advantages } \\
\text { (lower prices, gifts,...) to } \\
\text { holders of store credit cards" }\end{array}$ & 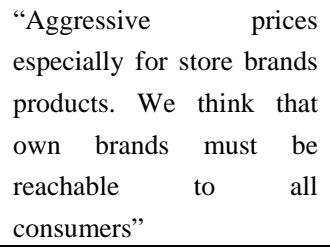 & $\begin{array}{l}\text { "Respect of the employees' rights } \\
\text { in terms of unionization, holidays } \\
\text { with pay, sick and maternity } \\
\text { leave, etc." }\end{array}$ \\
\hline $\begin{array}{l}\text { "First mover advantage in } \\
\text { the Brazilian market for the } \\
\text { hypermarket format" } \\
\text { "Localization in the heart of } \\
\text { the city for hypermarket" }\end{array}$ & $\begin{array}{l}\text { "Building leisure outlets } \\
\text { near the supermarket for } \\
\text { consumers' child" }\end{array}$ & $\begin{array}{l}\text { "All kinds of advertising } \\
\text { are considered" }\end{array}$ & $\begin{array}{l}\text { "We try to promote diversity of } \\
\text { our staffs" }\end{array}$ \\
\hline $\begin{array}{l}\text { "Managing to move in less } \\
\text { prosperous area of the town } \\
\text { with a supermarket format" }\end{array}$ & $\begin{array}{l}\text { "Trying to make the store } \\
\text { atmosphere funny as } \\
\text { consumers are now sensitive } \\
\text { to store environment" }\end{array}$ & $\begin{array}{l}\text { "We are in partnership } \\
\text { with many local suppliers. } \\
\text { We try to respect their } \\
\text { interests. We are working } \\
\text { on a win-win basis" }\end{array}$ & $\begin{array}{l}\text { "Our employees do their best to } \\
\text { achieve consumer satisfaction } \\
\text { while respecting our } \\
\text { organizational culture" }\end{array}$ \\
\hline
\end{tabular}




\subsection{Comparing Carrefour to the Local Chain Extra}

In order to have a more precise idea of the success of Carrefour in the Brazilian market, we explored the success of Extra (local challenger of Carrefour). The results are shown in table 1.

Table 2. Verbatim and dimensions of 'core competence' theory and organizational theory for the local chain Extra

\begin{tabular}{|c|c|c|c|}
\hline Store format and localization & Consumer relationship & Competitive strengths & Organizational culture \\
\hline $\begin{array}{l}\text { "Supermarket was our main } \\
\text { format." } \\
\text { "Retail format diversification is } \\
\text { now a reality for us as we are } \\
\text { present main retail formats } \\
\text { available in the Brazilian market" }\end{array}$ & $\begin{array}{l}\text { "We have always been a } \\
\text { customer oriented retail } \\
\text { company. Customer } \\
\text { satisfaction is a key } \\
\text { element of our strategy" }\end{array}$ & $\begin{array}{l}\text { "Our store brands is a means } \\
\text { to catch all kinds of } \\
\text { consumers" } \\
\text { "Providing the best price- } \\
\text { quality relation especially } \\
\text { with our own label products } \\
\text { which are now well known in } \\
\text { the market." }\end{array}$ & $\begin{array}{l}\text { "The level of adaptation is } \\
\text { high. We try to respond to } \\
\text { customers' needs by } \\
\text { prices". } \\
\text { "We try to embed our } \\
\text { organization values in the } \\
\text { minds of all our } \\
\text { employees" }\end{array}$ \\
\hline $\begin{array}{l}\text { "As discount lines are always } \\
\text { available in our stores, there is no } \\
\text { need to open discount store } \\
\text { formats currently" } \\
\text { "We are a challenger on the } \\
\text { Brazilian market. But we are } \\
\text { trying to develop all the relevant } \\
\text { retail formats in Brazil" }\end{array}$ & $\begin{array}{l}\text { "Launching four main } \\
\text { retail brands (low priced) } \\
\text { using a different name } \\
\text { from that of the store" } \\
\text { "Providing store credit } \\
\text { cards to consumers" }\end{array}$ & $\begin{array}{l}\text { "Investing in store image to } \\
\text { provide a more exciting retail } \\
\text { environment" }\end{array}$ & $\begin{array}{l}\text { "Giving a good } \\
\text { remuneration package but } \\
\text { also some team-building } \\
\text { activities to create a strong } \\
\text { and balanced corporate } \\
\text { culture" }\end{array}$ \\
\hline $\begin{array}{l}\text { "Even though it is not always } \\
\text { easy to settle in the heart of big } \\
\text { cities, we do our best to be close } \\
\text { to our customers" }\end{array}$ & $\begin{array}{l}\text { "Building leisure outlets } \\
\text { inside the supermarket for } \\
\text { consumers' children so that } \\
\text { consumers with kids can } \\
\text { shop peacefully" }\end{array}$ & $\begin{array}{l}\text { "We are mainly using } \\
\text { point-of-sale advertising to } \\
\text { promote our products, } \\
\text { especially our own products" }\end{array}$ & $\begin{array}{l}\text { We are aware of how } \\
\text { multi-cultural is Brazil. } \\
\text { This is why we are doing } \\
\text { our best to respect all the } \\
\text { Brazilian values and beliefs } \\
\text { within our company. }\end{array}$ \\
\hline $\begin{array}{l}\text { "We try to be present in every } \\
\text { district of the cities. We also } \\
\text { change the positioning of our } \\
\text { retail formats depending on } \\
\text { consumers' income in a given } \\
\text { area" }\end{array}$ & $\begin{array}{l}\text { "Based on our knowledge } \\
\text { of the Brazilian market, we } \\
\text { try to provide the best store } \\
\text { atmosphere to our } \\
\text { customers" }\end{array}$ & $\begin{array}{l}\text { "Most of our suppliers are } \\
\text { part of our company. So, it is } \\
\text { possible for us to control the } \\
\text { whole production chain and } \\
\text { provide good quality } \\
\text { services" }\end{array}$ & $\begin{array}{l}\text { "We encourage our } \\
\text { employees to be } \\
\text { responsible, not only } \\
\text { within the company but } \\
\text { also outside. We try to } \\
\text { make them ambassadors } \\
\text { who are proud to represent } \\
\text { their company" }\end{array}$ \\
\hline
\end{tabular}

Several comments can be made when comparing the success of the two retailers investigated in the Brazilian market. First, regarding 'store format and localization', Carrefour and Extra are now almost in the same situation. In fact, Carrefour uses supermarket as a key format for its internationalization whereas Extra is doing very well in this format today in Brazil. In terms of localization, Carrefour keeps an advantage as the first big mover on the Brazilian market. However, Extra is trying to be present everywhere in Brasilia. It also adopts the strategy of changing the positioning of its retail formats depending on consumers' income in a given area.

Second, regarding 'customer relationship', the success of the two retailers is based on similar facts. For instance, they both adopted a customer orientation and tried to build loyalty and reach customer satisfaction by launching their own brands and store credit cards. However, Extra has an advantage as it offers its leisure outlets for kids inside its hypermarkets whereas Carrefour built its leisure outlets for kids outside its stores. It's obviously more secure for clients to be able to see their kids while shopping.

Third, with reference to competitive strengths', the two retailers have a similar strategy. For example, they both own brands that try to attract every customer segment in the Brazilian market. However, where Carrefour put forward its aggressive pricing policy with its own brands, Extra emphasized the price-quality ratio of its own brands. Finally, concerning 'organizational culture', the two retailers have two main differences. On the one hand, Carrefour lays the emphasis mainly on standardization in order to make economies of scale and to offer low prices to consumer while Extra focuses on a higher level of adaptation to the local culture. On the other 
hand, Extra seems to be more concerned than Carrefour about the behavior of its employees even outside the working hours.

\section{Conclusions: Implications, Limitations and Future Research}

Retail internationalization is now a key element for most of the retail firms. Many factors lead to retail internationalization and are likely to influence the business strategy adopted in emerging markets. The main objective of this research was to investigate key success factors of an international retailer in the Brazilian market based on two increasingly interesting theories, i.e., 'core competence' theory and organizational cultural theory. Several implications can be highlighted from our analysis.

\subsection{Discussion and Research Implications}

In terms of theoretical implications, this research helps to better understand factors influencing international retail success factors in an emerging market. First, it's generally recognized that retail internalization is now a key strategic issue for retailers. This research showed that 'core competence' theory and organizational culture theory are, among other theories, relevant frameworks that can explain a retailer's success in an emerging market, especially in the Brazilian market. Second, this research contributes to a better understanding of emerging market countries. Following Burgess and Steenkamp (2006), we think that emerging market countries should devote more attention on market researchers. Several managerial implications of this study must be noted. First of all, managers must be aware that there are many different factors that can explain retailers' success in an emerging market. The 'core competence' theory and the organizational culture theory's facets highlighted here are part of these factors. Relevant store format, a good localization, a good management of customer relationship and competitive strengths are key factors to be taken into account in an emerging market like Brazil. Besides, following Prahalad and Hamel's recommendation to diversify an organization's staff as well as to review values and beliefs through an unlearning process, we recommend diversifying the retail staff in this emerging market (Brazil). Actually, emerging market countries are most of the time multi-cultural and it would be a mistake to pass over the multi-cultural nature of these markets, especially the Brazilian one. As for Carrefour, its strategy seems to have been relevant in the past. However, today, the strategy of Extra becomes more appropriate and more in line with consumer expectations. If Carrefour wants to keep itself in first position in the Brazilian market, it has to be more innovative regarding both 'core competence' and organizational culture.

\subsection{Limitations and Future Research}

The relevance of the Brazilian market as a field of study for the problems mentioned in our research and its objectives is obvious. However, this study is limited in that it was carried out in only one Brazilian city and includes managers from only two different retailers. This is why caution should be paid in generalizing the results of other emerging markets. Also, data collected in this research are partly based on the perceptions and statements of managers, assessing their firm's key success factors: they may have been tempted to embellish things in order to highlight their success on the Brazilian market.

Our findings permitted to define some directions of future studies. On the one hand, it would be useful to carry out more investigations about 'core competence' and organizational culture theories in the Brazilian market. This would help to figure out which one performs better in Brazil. Fleury (2009) investigated the effect of organizational culture and competence in this country but her research did not deal with the retail sector. Consequently, we could not generalize her results to the retail sector. On the other hand, it would be interesting to conduct this same study in other emerging markets. As emerging markets have different economic, political and institutional contexts, one could imagine that key success factors may differ from one country to another. Cao and Dupuis (2009) showed that 'core competences' was one of the best theories explaining retail internationalization in China. But how about organizational culture theory in China?

\section{References}

Alexander, N., \& de Lira e Silva, M. (2002). Emerging markets and the internationalization of retailing: The Brazilian experience. International Journal of Retail and Distribution Management, 30(6), 300-314. http://dx.doi.org/10.1108/09590550210429513

ATKearney. (2010). Expanding opportunities for global retailers. The 2010 ATKearney Global Retail Development Index, AT Kearney report. (accessed July 10, 2012) available at: http://www.atkearney.com/images/global/pdf/2010_Global_Retail_Development_Index.pdf

Barkema, H., Bell, J., \& Pennings, J. (1996). Foreign entry, cultural barriers and learning. Strategic Management Journal, 
Barney, J. B. (1991). Firm resources and sustained competitive advantage. Journal of Management, 17(1), 99-120. http://dx.doi.org/10.1177/014920639101700108

Burgess, S. M., \& Steenkamp, J. B. - E. M. (2006). Marketing renaissance: How research in emerging markets advances marketing science and practice. International Journal of Research in Marketing, 23(4), 337-356. http://dx.doi.org/10.1016/j.ijresmar.2006.08.001

Burt, S., Davies, K., Dawson, J., \& Sparks, L. (2008). Categorizing patterns and processes in retail grocery internationalization. Journal of Retailing and Consumer Services, 15(2), 78-92. http://dx.doi.org/10.1016/j.jretconser.2007.05.008

Cao, L. L., \& Dupuis, M. (2009). Core competences, strategy and performance: the case of international retailers in China. The International Review of Retail, Distribution and Consumer Research, 19(4), 349-369. http://dx.doi.org/10.1080/09593960903331360

Conner, K. R. (1991). A historical comparison of resource-based view and five schools of thought within industrial organization economics: Do we have a new theory of the firm? Journal of Management, 17(1), 121-154. http://dx.doi.org/10.1177/014920639101700109

Daft, L. R. (1983). Organizational theory and designs. St. Paul: West Pub. Co.

Dawson, J. (1994). Internationalization of retailing operations. Journal of Marketing Management, 10(4), 267-82. http://dx.doi.org/10.1080/0267257X.1994.9964274

Deshpande, R., Farley, J., \& Webster, F. (1993). Corporate culture, customer orientation and innovativeness in Japanese firms: A quadrant analysis. Journal of Marketing, 57(1), 23-37. http://dx.doi.org/10.2307/1252055

Diallo, M. F. (2009). Foreign retailers' private label brands strategy in emerging markets: Evidence from the Brazilian retail industry. The Business Review, Cambridge, 12(1), 127-133.

Diallo, M. F. (2012). Effects of store image and store brand price-image on store brand purchase intention: Application to an emerging market. Journal of Retailing and Consumer Services, 19(3), 360-367. http://dx.doi.org/10.1016/j.jretconser.2012.03.010

Dupuis, M., \& Fournioux, J. (2005). Internationalisation du distributeur: De l'avantage compétitif à la performance. Décisions Marketing, 37, 45-56.

Fleury, M. T. L. (2009). Organizational culture and the renewal of competences. Brazilian Administration Review, 6(1), 1-14. http://dx.doi.org/10.1590/S1807-76922009000100002

Grant, R. M. (1991). The resource-based theory of competitive advantage: Implications for strategy formulation. California Management Review, 33(3), 114-135.

Hofstede, G. (1981). Management control of public and not-for-profit activities. Accounting, Organisations and Society, 6(3), 192-211. http://dx.doi.org/10.1016/0361-3682(81)90026-X

Hutchinson, K., Alexander, N., Quinn, B., \& Dohery, A.-M. (2007). Internationalization motives and facilitating factors: Qualitative evidence from smaller specialist retailers. Journal of International Marketing, 15(3), 95-122. http://dx.doi.org/10.1509/jimk.15.3.96

International Monetary Fund. (2008). Report for selected countries and subjects. World Economic Outlook Database. International Monetary Fund Ducument, April.

Krippendorff, K. (2004). Content analysis: an introduction to its methodology. Thousand Oaks, CA: Sage Publications, Second Edition.

Meyer, K. E., \& Yen, T. T. T. (2006). Market penetration and acquisition strategies for emerging economies. Long Range Planning, 39, 177-197. http://dx.doi.org/10.1016/j.lrp.2006.04.004

Morgan, G. (1997). Images of organization. Thousand Oaks, CA: Sage Publications.

Ogbonna, E., \& Harris, L. C. (2002). Organizational culture: A ten year, two-phase study of change in the UK food retailing sector. Journal of Management Studies, 39(5), 673-706. http://dx.doi.org/10.1111/1467-6486.00004

Pederzoli, D. (2006). Conception and test of a comprehensive model of international strategy for retail companies. International Journal of Retail Distribution and Consumer Research, 16(4), 415-431. http://dx.doi.org/10.1080/09593960600844210

Planet Retail. (2007). Private label trends worldwide 2007. Available from http://www.planetretail.net/ 
Prahalad, C. K., \& Hamel, G. (1990). The core competence of the corporation. Harvard Business Review, 68(3), 79-91.

Sacramento, I., Almeida, V., \& Silva, M. (2002). The internationalization process of services firms: a two-case study in Brazil. Latin American Business Review, 2(2), 43-64. http://dx.doi.org/10.1300/J140v03n02_03

Salmon, W. J., \& Tordjman, A. (1989). The internationalization of retailing. International Journal of Retailing, 4(2), 3-16.

Treadgold, A. (1988). Retailing without frontiers. Retail and Distribution Management, 16(6), 8-12. http://dx.doi.org/10.1108/eb018382

Vida, I., \& Fairhust, A. (1998). International expansion of retail firms: A theoretical approach for future investigations. Journal of Retailing and Consumer Services, 5(3), 143-151. http://dx.doi.org/10.1016/S0969-6989(96)00056-2 